\title{
BROADCASTING AND THE ANTITRUST LAWS
}

\author{
VICTOR R. HANSEN*
}

Current questions of monopolization and restraints in the radio and television broadcasting industry have aroused serious interest and study on many sides. To review the role of the Justice Department's Antitrust Division in the study of such questions is the purpose of this article.

By a series of interrelated statutes, Congress has marked out government responsibilities, on the one hand, for antitrust enforcement and, on the other, for regulation of broadcasting activities. Section four of the Sherman Act leaves enforcement of that law to "the direction of the Attorney General."1 And section 15 of the Clayton Act imposes a like responsibility on the Department of Justice." The Federal Communications Commission, in contrast, has no power to enforce the Sherman Act and only limited authority, never thus far exercised, to enforce Clayton Act section seven against "common carriers engaged in wire or radio communication or radio transmission of energy." 3 In the statutory framework, there would seem to be little basis for conflict regarding the responsibility for antitrust enforcement.

More broadly, however, the Commission is obliged by statute to "generally encourage the larger and more effective use of radio in the public interest." "While conceivably the public interest in broadcasting might have been served by stringent regulation, actually Congress adopted a different method. As the Supreme Court put it in FCC v. Sanders Bros. Radio Station, ". . . the Act recognizes that broadcasters are not common carriers to be dealt with as such. Thus the Act recognizes that the field of broadcasting is one of free competition." With this in mind, former Commission Chairman McConnaughey, testifying before the Special Antitrust Subcommittee of the House Judiciary Committee, affirmed that the Commission "has the obligation ... to maintain a system of broadcast compatible with the antitrust laws." Underscoring the importance of competition, Congress did not see fit, for example, to grant the Federal Communications Commission power to give a broadcasting licensee any antitrust immunity. ${ }^{7}$ On the contrary, Congress directed the

* LL.B. I928, University of Southern California. Assistant Attorney General of the United States, in charge of the Antitrust Division, Department of Justice, since 1956; member of the California bar. Author, The History of the State Guard of California (1946); Tortuous Path of a Fiduciary: Preparation of Condemanation Cases for Trial (1954).

${ }^{2} 26$ STAT. 209 (1890), I5 U.S.C. \$4 (r952).

${ }_{3} 38$ Strat. 736 (I914), 15 U.S.C. \$ 25 (1952).

${ }^{3} 64$ STAT. II25 (1950), I5 U.S.C. \$2I (1952).

"50 STAT. I90 (1937), 47 U.S.C. \$303(g) (1952).

309 U.S. 470,474 (I940).

- Hearings before the Antitrust Subcommittee of the House Committce on the Judiciary on Monopoly Problems in Regulated Industries, 84th Cong., 2d Sess., ser. 22, pt. 2, vol. 1, at $3{ }^{113}$ (1956).

"In contrast, most other federal regulatory agencies have such power. For example, the Interstate Commerce Act provides that "any carriers ... participating in a transaction approved or authorized ... are hereby relieved from the operation of the antitrust laws. . ." 63 STAT. 485 (I949), 49 U.S.C. 
Commisșion to refuse a license to anyone whose license has been revoked by the judgment of a court in an antitrust proceeding. ${ }^{8}$ And even more important, section $3^{\text {r } 3}$ of the Communications Act itself specifies:

All laws of the United States relating to unlawful restraints and monopolies and to combinations, contracts, or agreements in restraint of trade are declared to be applicable to ... interstate and foreign radio communications. ${ }^{9}$

In the light of this provision, former Chairman McConnaughey agreed that even specific Commission approval of an exchange of stations does not render "antitrust prosecution by the Department of Justice impossible."10 Although, a recent court decision, which I shall discuss herein, would seem to be at variance with this conclusion, the Commission has stated for the record that

In the light of the provisions of the [Communications] act, the Commission has taken the position that an action by it in an adjudicatory proceeding finding a particular grant of a license to be in the public interest cannot and does not insulate that transaction from further challenge by the Department under the antitrust laws. ${ }^{11}$

Entry into broadcasting requires a license from the Commission, ${ }^{12}$ and that license is granted, assuming the availability of a channel in the area, upon a showing of the ability of the prospective licensee to serve the public interest. In determining whether entry should be permitted, the Commission has rigorously excluded consideration of economic factors relating to possible financial loss, even where in an exceptional case admission of a new station into the area could conceivably result in bankruptcy of prior licensees and possible cessation of service. ${ }^{13}$ Such a policy is the antithesis of that prevailing with respect to regulated industries and powerfully rebuts any claim that broadcasting is similarly regulated, with primary jurisdiction for enforcing the antitrust laws vested in the Federal Communications Commission. Thus, in the Sanders case, the Supreme Court held that Commission findings relative to potential economic injury were not a prerequisite to the granting of an additional license for an area, despite a plea by a pre-existing station that it was

\& (II) (I952); and see 62 STAT. 472 (I948), 49 U.S.C. $\$ 5$ (b)(9) (I952), pertaining to relief for antitrust liability for rate-making agreements. Similarly, the Shipping Act states that "every agreement [between carriers filed with the Federal Maritime Board] . . . lawful under this section shall be excepted from the provisions of sections I-II and I5 of Title I5. . ." 64 STAT. I274 (I950), 46 U.S.C. $\$ 8 \mathrm{I}_{4}$ (1952). And the Civil Aeronautics Act provides that "any person affected by any order made [by the Board relating to consolidation, merger, acquisition of control, or pooling agreements] ... shall be ... relieved from the operations of the 'antitrust laws' . . in so far as may be necessary to enable such person to do anything authorized, approved or required by such order." 52 STAT. I004 (1938), 48 U.S.C. $\$ 494$ (I952).

${ }^{8} 66$ STAT. 716, 47 U.S.C. $\$ 3 \mathrm{Ir}$ (1952):

${ }_{48}$ STAT. 1087 (1934), 47 U.S.C. $\$ 313$ (I952).

${ }^{10}$ Hearings, supra note 6 , at 3135 .

${ }^{11}$ Letter from Chairman George C. McConnaughey to Hon. Warren G. Magnuson, Jan. 3, 1957. See Hearings before the Senate Committee on Interstate and Foreign Commerce on the Television Inquiry, 84th Cong., 2d Sess. pt. 4, at 3II6, 3118 (1956).

1266 STAT. 714, 47 U.S.C. $\$ 307$ (a) (1952).

za The Commission has, however, considered economic factors in its rule-making proceedings allocating television channels. 
already losing money, that it would be caused further economic loss, and that the area might not be able to support both stations. The Court said $:^{14}$

Plainly it is not the purpose of the Act to protect a licensee against competition but to protect the public. Congress intended to leave competition in the business of broadcasting where it found it, to permit a licensee who was not interfering electrically with other broadcasters to survive or succumb according to his ability to make his programs attractive to the public.

Nevertheless, the Supreme Court seemingly left the door ajar for consideration of economic factors in one situation, i.e., where there was a real possibility "that both stations-the existing and the proposed-will go under with the result that a portion of the listening public will be left without adequate service. . .."15 Possible injury to the public, as distinguished from the pre-existing station, thus appeared to be the single exception.

Recently, the Commission attempted to go even further. In a striking opinion in In re Southeastern Enterprise (WCLE), involving a situation similar to that of the Sanders case, the Commission refused to consider the effect of economic factors on competition, even where there was a possibility of failure of both stations and interruption of service with consequent injury to the public. The Commission chose to regard the exception of the Sanders case as obiter and seized upon "this opportunity now to disclaim any power to consider the effects of legal competition upon the public service in the field of broadcasting." For if it were to concern itself with economic effects, the Commission argued that it would be put in the intolerable position of engaging in a detailed common-carrier-type examination of the existing station's efficiency, its proper rate of return, and the prices charged advertisers, etc., factors which it believed Congress had excluded from consideration in the broadcasting field.

\section{Summing up, the Commission said: ${ }^{16}$}

Restriction of competition is a corollary of exclusivity, and exclusivity is tolerable only by the application of public utility concepts or techniques. When common carrier techniques are employed in the broadcasting business to the extent necessary to accomplish the objectives urged upon us, a subtle, indirect, but nonetheless a real transformation from competitive regulatory practices to public utility regulation will inevitably result. This we deem contrary to the specific provisions of the Communications Act, the intent of Congress, and the interpretation of that Act in the Sanders case, supra.

Doubt has been cast upon this decision, however, by an order issued by the court of appeals in the course of reviewing Southeastern Enterprises. On a petition for stay of the order below, the court of appeals stated:17

\footnotetext{
14309 U.S. at 475 .

${ }^{15}$ Id. at 476 .

${ }^{10} 22$ F.C.C. 605 (1957).

${ }^{17}$ Fitch \& Kyle v. FCC, Case No. 13,868 (D.C. Cir. June 5, 1957). The same cause before the Commission was captioned In re Southeastern Enterprises (WCLE), 22 F.C.C. 605 (1957). Subsequently, the court, on rehearing, dissolved the stay, and the case was dismissed by agreement of the parties on August 13, 1957. However, the precise legal issue is now before the same court in Carroll Broadcasting Co. v. FCC, Case No. 14,104, in which oral argument is scheduled for February 4, 1958.
} 
... the probabilities of success appear to lie heavily with appellant; and unlike that case[Television Corporation of America $v . F C C$ ], the showing of irreparable injury here is sufficient when coupled with such probability of success, to justify a stay.

In view of this statement and other dictum of the court of appeals, the validity of the Southeastern Enterprises rule remains in doubt.

This is far from saying, however, that the Commission regulates no broadcasting activities which touch on the business relations of its licensees. ${ }^{18}$ For example, the Chain Broadcasting Rules, although addressed in terms to station licensees, actually govern specified relationships between stations or applicants and networks. ${ }^{19}$ The Commission, after hearings, has at least inferentially sanctioned many of the contractual provisions between stations and network. Hence, regardless of whether such a sanction can grant legal immunity from the antitrust laws, it is obvious that, as a practical matter, the Antitrust Division, shaping its antitrust proceedings, should consider the scope and content of Commission regulations and their impact on broadcasting practices of antitrust significance. Conversely, the Commission is obligated to explore, as highly pertinent to the public interest, the antitrust implications of broadcasting conduct it regulates.

This statutory framework and administrative background lends perspective to the pending civil suits and investigations of the Antitrust Division in the broadcasting field. Initially, two antitrust civil cases against broadcasters were pending in the courts, one of which has been dismissed; six other antitrust cases involving television have been filed against distributors of feature film for telecasting. More broadly relevant are pendng investigations of television network tie-ins and talent control and the Division's current analysis of the antitrust questions posed by the television networks' "must buy" and option-time policies. Finally, underpinning all these inquiries is the basic issue of whether, in today's market context, the networks" multiple role-program production, talent control, program distribution, and station ownership-so threatens television competition as to warrant antitrust remedy, perhaps including divestiture or divorcement.

\section{Pending Litigation}

United States v. Radio Corporation of America. ${ }^{20}$ In June 1955, NBC and Westinghouse Broadcasting Company sought Commission approval of an exchange of WBC's radio and television stations in Philadelphia for NBC's stations in Cleveland plus $\$ 3,000,000$. On December 21, I955, following an investigation by its staff, the Commission voted to grant the joint application, and the stations were exchanged one month later.

In June 1956 , a federal grand jury in Philadelphia undertook an investigation

\footnotetext{
${ }^{18}$ Television broadcasting, for example, is carried out pursuant to Subpart $\mathrm{E}$ of the Federal Communications Commission's Rules Governing Radio Broadcast Services, 47 C.F.R. c. I, pt. 3 (Supp. I956).

${ }^{10}$ NBC v. United States, 3 I9 U.S. 190, I96 (1943).

${ }^{20}$ Civil No. 21743, E.D. Pa. 1956.
} 
of the circumstances of this station exchange, and on December 4, 1956 , a civil antitrust action which charges RCA and NBC with violations of section one of the Sherman Act was filed in the United States District Court for the Eastern District of Pennsylvania.

The complaint alleges that the defendants unlawfully combined or conspired to obtain VHF (very high frequency) television station ownership for NBC in five of the eight largest markets of the United States by the unlawful use of NBC's power as a network to grant or to withhold NBC network affiliation from nonnetwork station owners. In March 1954, the approximate date when the conspiracy is alleged to have begun, NBC owned and operated VHF television stations in New York, Chicago, Los Angeles, Cleveland, and Washington.

The conspiracy is alleged to have been carried out, in part, by NBC's acquisition in Philadelphia (the nation's fourth largest market) of television and radio stations (WPTZ and KYW) formerly belonging to Westinghouse. This acquisition is alleged to have been accomplished by a threat that if Westinghouse would not agree to the exchange, it would lose its NBC affliation in Boston and Philadelphia, it would not be granted NBC affiliation for a station which it was acquiring in Pittsburgh, and it would not obtain NBC affiliation for its future television stations when acquired. The complaint also alleges that the contract of May 16, 1955, by which Westinghouse agreed to exchange its Philadelphia stations for NBC's Cleveland television and radio stations (WNBK and WTAM-AM and -FM) and $\$ 3,000,000$, was itself in unreasonable restraint of trade and therefore in violation of the Sherman Act.

The complaint further alleges that the illegal activities of NBC and RCA have reduced Westinghouse's ability to compete with NBC and other station owners in the sale of advertising, have eliminated competition among independent station representatives for representation of the acquired television station in Philadelphia, have precluded competition among station owners in Philadelphia for NBC network affiliation, and have reduced the competitive ability of Westinghouse's parent company, Westinghouse Electric Corporation, against RCA and others in the sale of equipment for the transmission and reception of radio and television signals.

The complaint requests the court to declare unlawful the combination or conspiracy between RCA and NBC, and the contract between NBC and Westinghouse. It also requests such divestiture of NBC's assets as the court may deem necessary and appropriate under the Sherman Act and section $3^{13} 3$ of the Communications Act.

RCA and NBC, by joint answer, pleaded five separate defenses to the charges. The first denied the existence of the conspiracy charged in the complaint and further denies that the contract between NBC and Westinghouse involving the station exchange is in unreasonable restraint of trade. The answer alleged the existence of facts involved in the FCC approval of the exchange of licenses by NBC and Westinghouse and certain facts involved in the relationship between the FCC and the Department of Justice during the pendency before the FCC of the matter of approval of the exchange of licenses. On the basis of these alleged facts, the defendants 
sought to invoke the doctrines of administrative finality, lack of jurisdiction over the subject matter, res judicata and collateral estoppel as barring the Government's cause of action.

On January 10, 1958, the district court ruled that these defenses were valid and constituted a bar to the prosecution of this suit. The decision concluded that the orderly administration of law required dismissal of the action.

Whatever the ultimate outcome of the litigation, this much is clear. First, the $N B C-R C A$ case poses squarely the question whether approval of a broadcasting license by the Commission can oust the district courts of jurisdiction to enforce the antitrust laws. Second, the roles of the parties to this exchange underline the disparate bargaining power of a station owner, even as large as Westinghouse, in its relations with the major television networks.

The Philadelphia Radio \& Television Broadcasters cases ${ }^{21}$ involved an alleged agreement by Philadelphia broadcasting stations and their local trade association not to deviate from their published rate card rates. On June 27,1956 , a grand jury returned an indictment against the association, nine radio stations, and ten of their officers for violation of section one of the Sherman Act. This was followed by the filing on August 3, I956 of a companion civil suit seeking (a) termination of the alleged price-fixing agreements, (b) cancellation of the association's bylaws implementing the freezing of rates, and (c) the adoption of new bylaws making membership in the association contingent upon compliance with the judgment. On June I3, 1957, the association pleaded guilty in the criminal action and was fined $\$ 5,000$. The incorporated defendant radio stations were permitted to enter pleas of nolo contendere and were each fined $\$ 1,000$, and the indictments against the individual defendants were dismissed. The civil suit is still pending.

In March and April 1957, six separate antitrust actions were filed in the Southern District of New York against the major distributors of feature film for television, ${ }^{22}$ alleging violations of section one of the Sherman Act by the compulsory blocbooking of copyrighted feature films to television. Each complaint alleges that the respective defendant company has required television stations to license its pictures in groups. In order for a station to obtain any of the pictures in the group, it is claimed, the station is required to take not only the pictures it wants, but also a number which it does not wish to license or televise. In addition, the complaints assert that the alleged restraint has caused the playing time of television stations to be arbitrarily pre-empted by the defendants' films, thereby preventing stations from ex-

${ }^{21}$ United States v. Philadelphia Radio \& Television Broadcasters Ass'n, Crim. No. I8872, Civil No. 21138 E.D. Pa. I956.

2a The television distribution companies named as defendants are the following:

Loew's, Inc. (MGM Pictures), Civil No. I19-24

C \& C Super Corp. (RKO Pictures), Civil No. 119-284

Screen Gems, Inc. (Columbia Pictures), Civil No. IIg-285

Associated Artists Productions, Inc. (Warner Bros. Pictures), Civil No. II9-286

National Telefilm Associates, Inc. (2oth Century-Fox Pictures), Civil No. rIg-287

United Artists Corporation (United Artists Pictures), Civil No. II9-288. 
hibiting the films of other producers and distributors. It is maintained, moreover, that stations financially unable to purchase in the large groups required to be taken have been unable to buy any of the defendants' films. Finally, the appearance of many old and poor quality films on television today is attributed to the existence of the allegedly unlawful bloc-booking contracts.

The respective prayers for relief ask that the defendant company be required to license picture-by-picture and station-by-station, and that the defendant offer to renegotiate the existing contracts.

Discovery proceedings are now in process.

II

\section{Tie-Ins and Talent Controx}

Great disparity in power between the networks and other elements of the industry is revealed by the current investigation of charges that television networks require sponsors to use network-owned programs. The complaints are against network tie-ins of sales of television network time to sales of shows owned or controlled by the network-in other words, that networks (acting individually) sometimes offer desirable time slots, in what is usually called "prime time" (7:30-10:30 in the evening), to sponsors only on condition that these sponsors use shows in which the networks own an interest.

This investigation of asserted television network control over shows and talent began more than two years ago. After preliminary inquiries revealed that further investigation was warranted, in March 1956 , a broad, general inquiry was launched into network practices relating to the sale of television network time and shows. Individuals and companies functioning at every level of the television industry were interviewed. These included advertising agencies, television program producers and distributors (of both live and film), station representatives, network officials, and sponsors.

Integral to this broad inquiry is investigation of long-term talent contracts. Underscoring its relevance is the tale of prior governmental action against restraints on radio talent. In 194I, the Federal Communications Commission promulgated its Chain Broadcasting Rules for radio. NBC and CBS promptly sued the Commission to enjoin their enforcement. ${ }^{23}$ While these actions were pending, in December I94I, the Department of Justice brought suits against the same networks alleging conspiracies in restraint of trade and attempts to monopolize interstate commerce in radio broadcasting, electrical transcriptions, and talent. These complaints alleged that the networks were "... insisting that the advertisers and advertising agencies using time on defendants' networks likewise use the services of talent under contract to defendants." In May 1943, the Supreme Court upheld the authority of the Commission to promulgate the Regulations. ${ }^{24}$ Soon after, on October 18 , 1943, the

\footnotetext{
ss See NBC v. United States, 44 F. Supp. 688 (S.D.N.Y. 1942), rev'd, 316 U.S. 407,447 (1942).

"NBC v. United States, 319 U.S. 190 (I943).
} 
Government moved to dismiss its antitrust complaints, since both networks had sold their artists bureaus and the Commission apparently had power to regulate any reacquisition. Against this background, the present inquiry is whether the networks now insist in television (as they allegedly did in radio) that advertisers use network shows in which network talent appears as a condition to the purchase of choice network broadcast time.

\section{III}

\section{Network Time Sales to Advertisers}

A corollary to this inquiry into network television show production practices is the Antitrust Division's investigation of network time sales to advertisers which commenced in the summer of 1956 . This inquiry aims to determine whether the procedures by which the networks distribute product-in other words, the methods by which they sell broadcast time on their own and their affliated television stationsviolate the antitrust laws. It also concerns the demand for and supply of television network time, as well as discounts and rebates offered to advertisers by the networks.

One practice employed by all three networks is the so-called "must buy" policy. This policy requires the advertiser, if he desires to use the network at all, to purchase broadcasting time on a large number of television stations. This "package" procedure varies somewhat between networks. Thus, CBS requires a network sponsor to advertise on all five of the television stations it owns, ${ }^{25}$ plus $5^{\mathrm{I}}$ designated affiliated stations. (The minimum time rate for an evening hour on the CBS network exceeds $\$ 70,000$.) Similarly, NBC requires the advertiser to buy time on its own six television stations, plus $5 \mathrm{I}$ designated affliates. NBC's rate card further provides that, to obtain normal discounts, the advertiser using prime evening time must also broadcast his program over 43 additional affiliates-for a total of roo stations. As a result, such package's minimum cost for an evening hour on NBC is approximately $\$ 90,000$. Until recently, $A B C$ 's policy required an advertiser to utilize all five of the $A B C$ owned stations and such additional affiliated stations as would provide a minimum time charge of $\$ 50,000$ per Class A (evening) hour. Last spring, ABC dropped the requirement that time on its owned and operated stations be purchased and increased its minimum time charge to $\$ 60,000$. The networks refer to the stations on the "must buy" list as "basic required" stations, "available only as a group."

The "must buy" policy relates to, and derives support from, the networks' control of their affiliates' prime telecasting time, effected by time options. "Option time" is industry shorthand for the contractual arrangements between a network and its affiliated stations by which the network receives an option to require the stations to take network programs, with certain exceptions, for a specified number of hours each day. Since 194I, when the Federal Communications Commission promulgated its Chain Broadcasting Rules, option time has been regulated. These regulations provide that television broadcasting stations may not option ${ }^{26}$

${ }^{28}$ In addition, CBS has applications pending before the Commission to acquire television stations in Philadelphia and St. Louis.

${ }^{80}$ FCC Regulations, 47 C.F.R. $\$ 3.658$ (d) (Supp. 1956). (Emphasis added.) 
... for network programs any time subject to call on less than $5^{6}$ days' notice, or more time than a total of 3 hours within each of four segments of the broadcast day . . . as follows: 8:00 a.m. to I:00 p.m.; r:00 p.m. to 6:00 p.m.; 6:00 p.m. to Ir:00 p.m.; Ir:00 p.m. to $8: 00$ a.m. ... Such options may not be exclusive as against other network organizations and may not prevent or hinder the station from optioning or selling any or all of the time covered by the option, or other time, to other network organizations.

In addition, the Regulations provide that broadcasters may not have any arrangement with a network which

prevents or hinders the station from rejecting or refusing network programs which the station reasonably believes to be unsatisfactory or unsuitable or ... which .... in its opinion, ... [are] contrary to the public interest, or from substituting a program of outstanding local or national importance.27

The Federal Communications Commission's Chain Broadcasting Rules stem from the Commission's powers to regulate the operation of the stations it licenses to serve the public interest under Title three of the Communications Act of 1934. The Commission has no such licensing power over networks, and its rules are, therefore, necessarily directed against practices of the individual stations engaged in chain-broadcasting or network ownership of stations. Since the "must buy" arrangements are between the networks and the television advertisers, some question has been raised as to the Commission's authority to regulate these relationships. No such regulations presently exist, but the problem has been studied by a special Network Study Group of the Commission.

The Antitrust Division has launched an investigation of the effects of "must buy" upon advertisers and the television industry. In this connection, it gave careful consideration to the legal opinions submitted to the Senate Interstate and Foreign Commerce Committee by critics of the television networks who contend that the "must buy" policy is illegal under the doctrines of United States $v$. Griffith, ${ }^{28}$ and United States $v$. Paramount Pictures, Inc. ${ }^{29}$ In addition, it also studied the several legal briefs submitted to the same senate committee by the networks defending this business practice as reasonable, necessary, and unrestrictive. It is contemplated that in the course of this investigation, numerous persons with knowledge of this field will be interviewed in an effort to obtain a wide variety of information concerning network procedures for selling time to advertisers.

\section{IV}

\section{Network OWNership of Stations}

In addition to their pre-eminence in networking and program production and their control of network time sales to advertisers, $A B C, C B S$, and NBC are also three of the most important owners of television stations in the nation today. NBC now

${ }^{27} I d . \$ 3.658(\mathrm{e})$.

${ }^{28} 334$ U.S. I00 (1948).

${ }^{29} 334$ U.S. 13I (I948). 
owns VHF stations in New York, Chicago, Los Angeles, Philadelphia, and Washington-the nation's first, second, third, fourth and tenth largest markets respectively; it also owns UHF stations in Buffalo and Hartford. ABC owns VHF stations in the first, second, third, fifth (Detroit) and sixth (San Francisco) largest television markets; it has no UHF stations. CBS owns VHF stations in the first three largest television markets and has applications pending for VHF stations in Philadelphia and St. Louis, the nation's ninth largest market; it also owns UHF stations in Milwaukee and Hartford. Senator John Bricker reported to the Senate Committee on Interstate and Foreign Commerce that "NBC . . . includes 23 per cent of the country's population within the service areas of its owned stations."30 Similarly, the President of CBS conceded, in his testimony before a senate subcommittee, that CBS covers "approximately 20 per cent of the population with its owned stations." ${ }^{11}$ The equivalent figure for $A B C$ is slightly under I9 per cent. ${ }^{32}$

Recognition of the fact that multiple ownership of stations breeds concentration of control appears in the Federal Communications Commission Regulations, which provide: ${ }^{33}$

Multiple Ownership. (a) No license for a television broadcast station shall be granted to any party .... if the grant of such license would result in a concentration of control of television broadcasting in a manner inconsistent with public interest, convenience, or necessity. In determining whether there is such a concentration of control, consideration will be given to the facts of each case with particular reference to such factors as the size, extent and location of area served, the number of people served, and the extent of other competitive service to the areas in question. The Commission, however, will in any event consider that there would be such a concentration of control contrary to the public interest, convenience or necessity for any party or any of its stockholders, officers or directors to have a direct or indirect interest in, or be stockholders, officers, or directors of, more than seven television broadcast stations, no more than five of which may be in the VHF band.

The Commission itself, in its Report on Chain Broadcasting in I94I, said that it would oppose network ownership of stations if it were deciding the matter ab initio. It justified continuation of network station ownership only because substantial interests had developed in reliance upon its tolerance of the situation. The Commission deplored the trend toward concentration of ownership and control of radio stations. The same trend has been observed with respect to television.

Ownership of a large number of stations by a single interest raises real antitrust problems. Such an owner would be in a position to use tactics similar to those of the Griffith, Schine, and Crescent motion-picture circuits by using a dominant position in one station area to obtain an advantage for a less desirable station. In fact, we have received complaints that those tactics have already been employed by multi-

${ }^{30}$ Senate Interstate and Foreign Commerce Committee, The Network Monopoly, 84th Cong., $2 \mathrm{~d}$ Sess. 24 (1956).

i2 24 Report of Proceedings before the Senate Commitee on Interstate and Foreign ConMerce ON THE TElevision INQUiRT 3344 (June I3, I956).

${ }^{39}$ U.S. Bureau of the Census, Dep't of Commerce, Summary-Census of Population, 1950, Population of Standard Metropolitan Areas P-A-r, table 26.

${ }^{30} 47$ C.F.R. $\$ 3.636$ (Supp. 1956). 
station owners who obtain perferences in network affiliations over single-station owners and who obtain preferences in the purchase of important packages of feature film.

It is my considered opinion that the FCC's multiple-ownership rule should, if anything, be tightened, not relaxed. Any liberalization of the rule would tend to increase the trend toward concentration of control. Such concentration is undesirable and inconsistent with antitrust objectives, whether the control is vested in networks or in others.

\section{$\mathrm{V}$}

\section{Summary and Conclusions}

The Network Study Group of the FCC made its final report on network broadcasting last year. ${ }^{34}$ This special and expert group has made recommendations for more stringent FCC regulation of television network practices. Also, its report has attempted to define more explicitly the lines of jurisdictional responsibility between the FCC and the Antitrust Division.

The Antitrust Division's current investigation of network control over talent and program production, though not yet complete, suggests that the principal networks have power to dominate if not control all aspects of television programming. For example, the CBS network, based on figures it supplied to congressional committees, produced alone or in association with other producers half the programs shown on its network. This power, it seems clear, spills over simple network distribution of entertainment to engulf program production, program syndication, station representation, and talent.

With such a pattern of dominance in program production, the present inquiry focuses on whether that power has been, or will likely be, used to exclude competition, thus violating section two of the Sherman Act. It also seeks to determine whether, in violation of section one, networks do "tie" sales of network time to the use of shows in which networks own an interest or control.

Beyond questions of network "tie-ins," there is the question whether the "must buy" policy of the television networks tends to coerce advertisers into the purchase of network television time on stations which they do not want. In fact, it may be determined that television advertisers accept network-picked packages of stations because of the networks' control, via time options, of prime telecasting time. 'The "must buy" policy appears to be closely interrelated with option time.

Appraisal of the impact of network practices upon television advertising requires examination, among other things, of available alternatives to network advertising. Statistics indicate that television advertisers spend considerable money each year on both local and national spot television advertising. In the aggregate, these two forms account for more than half of the advertising expenditures for television time. How-

s4 FCC, Network Brondcasting, Report of the Network Study Staff to the Netwonk Study CoMmItTEe (1957). 
ever, this need not mean that these forms of television advertising are equivalent to or provide satisfactory substitutes for network telecasting.

In addition, there is some prospect that "must buy" may unduly restrict the chance of the independent competing television station to sell time to an advertiser already tied to the network affliate. This power offers opportunity for special abuses in cities or towns having only one or two VHF stations. There, a network may be tempted to use the dominant position its affiliate may hold to force the sale of time on affliated stations in more competitive cities via "must buy."

In the course of the several current inquiries which attempt to judge whether these or other broadcasting business practices transgress the antitrust laws, it is natural to look for an analogous industry. To many lawyers, there appears a striking similarity between the television industry structure and that movie pattern condemned in the Paramount case. ${ }^{35}$ The Court there held the eight defendants, acting in combination, had monopolized the movie exhibition business in first-run theatres via practices such as "pooling agreements," which violated the Sherman Act. Defendants in combination were found to possess not merely monopoly power over the price at which films were exhibited in theatres, but power based on theatre control to deny to their rivals access to first-run theatres.

Now compare, if you will, the Paramount defendants' power based on theatre control with the networks' dominance based on station control. "The five majors in 1945," the Paramount Court found, "had interests in somewhat over 17 per cent of the theatres in the United States-3,137 out of 18,076." Moreover, again in the language of the Supreme Court, "in the 92 cities of the country with populations over I00,000 at least 70 per cent of all the first-run theatres are affiliated with one or more of the five majors." ${ }^{36}$

Networks' control over the nation's TV stations dwarfs the majors' power over theatres condemned in Paramount. As of July 29, 1957, Broadcasting-Telecasting (a recognized trade publication) reports that there are 389 VHF television stations and 88 UHF stations-or a total of 477 commercial TV stations in this country. Of this 477 , about 45 are independent stations, with no network affiliation. From these statistics, it seems clear the networks own or have affiliation agreements with more than 90 per cent of the television stations in this country.

The present investigations should elicit answers to questions of power and purpose. Network practices like "must buy," option time, control of programming and the "tying" of shows to time sales would evidence network dominance, a matter crucial to a Sherman Act monopolization charge under a section two inquiry. Beyond that, such practices may violate section one.

st 334 U.S. 131 (1948)

so Id. at 167 . 